\section{Flood of discoveries in Nepal!}

\author{
Access to full text of world's 7000 leading journals \\ will revalue the role of TUCL
}

\section{Krishra M Bhandary}

S G ALBERT IS REPORTED TO HAVE SAID that research is to seewhateverybodyelsehas seen and to think what nobody else has thought. And, thinking to generatenew ideas should al ways be preceded by looking at the generated ideas. Since new knowledge is mostlyannounced viajournals, theyareindispensable components for scientists and experts both to get generated knowledge and to publish their new ones. Recently, there has been a remarkable progress in the former in Nepal.

In February2003the International Networkfor theAvailability of ScientificPublications (INASP), a cooperative network established in 1992 by the International Council for Science

y (ICSU)asaprogrammeoftheCommitteeforthe

Dissemination of Scientific Information (CDSI),

brary(TUCL) as National Coordinating Institute for the implementation of its Program for EnhancementofResearch Information (PERI). The purpose of this collaboration is availability of newknowledgein digital form to Nepal. September 2003, the full texts of 7,000 scholarlyjournals as well as abstracts and contents of 20,000 journals from around the world will be accessible at TUCL and certain other centresdesignated by TUCL. Thejournalsareprimarily technical, and represent a broad range of scientific fields, includingmedicine, agriculture, forestry, natural resource management, and engineering, as well as other fields in the social sciences, humanities and business administration.

As the increasing gap between haves and have-nots poses an increasing threat to world stability, it is essential that Nepal and other developing countries take steps to

List of selected PERI resources for Nepal

\begin{tabular}{ll}
\hline EBSCO & $\begin{array}{l}\text { Full text of 6000 journals; abstract and content of 7300 journalsin } \\
\text { all branches of science, technology, medicine, social science, } \\
\text { humanities }\end{array}$ \\
\hline Blackwell Synergy & $\begin{array}{l}\text { Full text of over 600 leading journals in natural, physical, and } \\
\text { social sciences; technology; medicine; and the humanities }\end{array}$ \\
\hline Springer Verlag & Full text of 432 high-quality journals in many disciplines \\
\hline Oxford University & $\begin{array}{l}\text { Full text of over 120 leading journals in science, technology, } \\
\text { medicine, humanities and social science }\end{array}$ \\
\hline Emerald & $\begin{array}{l}\text { Full text of 100 journals in marketing, business, engineering, } \\
\text { material science }\end{array}$ \\
\hline CAB Compendium & $\begin{array}{l}\text { Many journals in agriculture, forestry, management, and } \\
\text { conservation of natural resources }\end{array}$ \\
\hline Cochrane Library & Good resourcefor medical and health science \\
\hline
\end{tabular}
with Danish Ministry ofForeign Affairs (DMFA) ơ nominated Tribhuvan University Central Li- strengthen their scientific base. Researchers, academicians and students in Nepal are expected to benefitgreatly from theprogram. At present, they cannot purchase subscriptions to western journals even if they wish to. This availability of full-text database can radically alter theway they think and thewaythey conduct research, eventually leading to better designed research projects and to more productive application of established ideas. To a significant extent, this program is expected to fulfil the demand for research results in Nepal.

The information resources of PERI would normally cost over onemillion pounds sterling. PERI pays this sum to the publishers. These resources have been made availableto usfor $£ 27,500$. INASP has madearrangements to cover costsfor 2003. Bravo, DMFA!Although there is some hope of obtaining funding for 2004 and 2005 from DMFA and the International Department for Foreign Affairs (DFID), it would bewisest to think consider how costs can bemet if donors do not materialize. Once theinformation resourceis available, TUCL can offer access to other institutions at no further cost. TUCL is working out detailsfor extension of access to all libraries, research institutions, colleges and not-for-profit educational institutes throughout Nepal.

Promoting quality publications in the countries where the programmme is implemented is also one of the objectives of PERI which puts them on its websitefor worldwide dissemination. This would benefit Nepalese publication to get international recognition.

Krishna M Bhandaryislibrarian of Tribhuvan University Central Library, Kathmandu, Nepal. E-mail:tud@healthnet.org.np

\section{Marketing science journals

\author{
The wide circulation of a \\ journal is as important as
} its publication}

\section{Bharat B Shestha}

A HUGE AMOUNT OF INFORMATION IS generated every year in thefield of scienceand technology. Many scientists from different countriesareworkingon similartopicseither in co-operation or independently. The research findings of onescientistareimportant for othersin solvingmany problems. Research communication also avoids overlap in research and savestimeand resources. Theexchangeof information and ideas among them is very important to achievegoals earlier. Regular meeting between them is, however, impossible. Publication in electronic media or in printed form (e.g., journals) and widecirculation isthe most appropriate means of communication. Primary information is mostly fragmentary. These fragments should be distributed to the interested peoples. Research results will not have any meaning unless they are published and circulated. A good journal is a forum in which peoplesfrom different regions can communicate, shareideas, discuss and solve problems.

Therearealargenumber of good journals in the international market but very few have found their place in libraries of our university and research centers. Thisterriblelack of accesstosuch journalshampersour research and education al though their availabilityisnot going to make a great contribution to our research and development. Thisisbecausethere is a huge gap between the studies addressed by such journals and those conducted by our scientists. Journals published in Nepal are thereforecritically important, for theycan bea platform for our scientists.

When we count the number of science journals published in Nepal, perhapswearenot poor.Thisisgood news. Butthebad newsisthat many of them arevery poor in quality, irregular in publication and have very limited distribution. Theyareprinted on low-gradepaper with a shortlifespan. Manyannual journals arepublished at an interval of several years. For many journalsasingleissuebecomesthefirstand last. The Ministry of Science and Technology published thefirstissueof ScientificWorld in 1999and a second issuehas not appeared yet!

Limited distribution of published journalsisamajor problem in scientific communication. A journal is published, piled up in the publisher's office and ultimately damaged by silverfish or sold to a paper collector as waste paper. A better approach can besaleat reduced priceor freedistribution to interested people. Theproceedings of the first (1988) and second
-

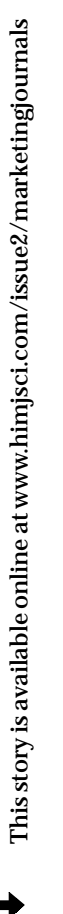


(1992) National ScienceConferenceorganized by RONAST were distributed free of cost to participants of Third National Conference in 1999. Although reduced sales undermine the aim of publication, there is another aspect to this problem. The author visited the office of the dean of the Institute of Science and Technology (IOST,TU) to collect the recentissue of the Journal of Instituteof Scienceand Technology. But thestorekeeper said thathecould not give out the journal because it had not been decided to distribute or sell it, even a month after publication. The samewas the case with Banko Janakari, published by the Forest $\mathrm{Re}$ search and Information Service Center (FRISC). Science Reporter, published by the National Institute of ScienceCommunication and Information Resource (India), isavailable in theshops of Nepal; whynot thepublications of RONAST, IOST and FRISC?

If wecannotensurethatajournal iseconomically self-sustaining, wecan know that it is goingto perish soon. Peoples arerealizingthe importanceof publication and thenumber of readersand customer is increasing. Researchers are facing difficult problems and have to wastemoretimegettinginformation. Ifitiseasilyavailablein timethey do nothesitateto pay aminimal price. So thefirst thingtodo isto improve the quality of journals in content and printing. Articles should be reliable and reviewed by experts. A good journal has an expanding market and peoplecan pay a reasonable price. Sometimes it may be necessary to encouragepeopleto buy thejournals by highlighting its significance. Journals and other publications of government organizationsare distributed free of cost but are not availableto all interested people. If you do not haveaclose relation with officialsyou haveto request several times to get a singlecopy, and sometimes even then you will not succeed!This situation needs to be corrected promptly. If they are published in sufficient number, sold at price that reflects their actual cost, and madeavailableon the public market (e.g. in book shops) thejournalswill notlosemoney, and interested peoplecan get information easily. For this it is necessary to improvethedistribution system. Booksand journals published by ICIMOD (International Centre for Integrated Mountain Development), IUCN (International Union for NatureConservation), NEFAS(Nepal Foundation for Advanced Studies) and other organizations are easily available in bookstores, but whynotjournals sublished by RONAST, ministry and TU? Major journals published by ministries, RONAST and TU should find a place in every library at academic institutions, re search centers, NGOs and INGOs. Publishers can use existing book distributors to make them availableto thegeneral public. And, one important thing that is to beremembered from time to time is that a journal not available to thosewho want and need it is not worth publishing.

Bharat B Shrestha is a teaching assistant at Central Department of Botany, Tribhuvan University. E-mail:bhabashre@yahoo.com

\title{
WTO casts a shadow over Nepal's natural legacy
}

\author{
Can't live with it, can't live without it. Confused? \\ The golden rule: Economic priorities should not be \\ allowed to outweigh environmental imperatives
}

\section{Krishna Rda}

APART FROM THE CURRENT POLITICAL turmoil, the major debate in our news media focuses on theissue of when Nepal should becomea member of theWorld TradeOrganization (WTO). Globalization has erased boundariesamongnationsthrough economic, social, and environmental unification. This is a case of "can't live with it, can't live without it." The real question hereinvolvestheenvironmental consequencesifNepal doesopen itsdoors, for globalization has paradoxically brought forth new problems rather than solvingold ones. The Northern bloc has long squandered the re sources of developing countries in thenameof economicprogress.

Globalization in effectisnotasingleprocess but a concatenation of developments involvinginfrastructureenhancement; economic reforms, tradeand market access, resourceextraction, production and distribution of goods, and so on. Themain thrust of globalization isto increase trade by increasing production. The expansion of urban societies hasincreased the demand for forest goods, from timber and pulp to medicinal plant, puttingever greater pressure on forest ecosystems. In recent decades, the pressures have intensified. Growing appetites for forest and agricultural products are driving loggingand conversion. ThePhilippines' loss of 90\% of itsprimaryforestduringthetimberboom of the 1970sisaclear exampleof our shortsightedness (1). The loss started after the Second WorldWar.TimberfromthePhilippineswassupplied to marketsin Europeand Japan afterWorld War II, as war-ravaged countries rebuilt. Every year, forested areas four times the size of Switzerland are cleared worldwide (2). Foreign investment in logging, mining, and energy contributesto this deforestation. Theseenterprises are the wheels on which the globalization juggernautcareensaround the world.

Under the circumstances, Nepal must thinktwicebeforeopeningitsborders. As Nobel laureateandformerchiefeconomistof theWorld BankJ oseph Stiglitzsays, "theborderless world through which goodsand servicesflowisalso a borderlessworldthrough whichotherthingscan flow that are less positive". Economic priorities should notbeallowed to outweigh environmental imperatives. Thegreatest threat posed byglobalization may be in the field of intellectual property rights (IPR). According to WTO rules, foreign companiesand individualsmaypatent productsand processeson which Nepaleselive lihoods have depended for centuries.
Multinational companies (MNCs) are pryingon developing countries with lesseffectivecentral authority, gainingaccess to their assets with little effort. Taking advantage of the situation, they swiftly take over the country's business sector in their control. FortheMNCs, economicreturn isall thatmatters; their rolein squandering natural resources has becomea sorepoint in many developingnations.

With economic liberalization, borders areopen for thefreeexchangeofideas, culture, and technology. Via satellite, western products have flooded thescreens of developing countries. Traditional ways havebeen transformed, as we haveopted for a McDonal dized (urbanized) culture. McDonaldization of thesociety demands morefood that both aggravateseconomic problemsand increases pressureon the environment. Traditional agricultural practices have proven inefficient in meeting modern demands. Farmers have adapted to using excessiveamount of chemical fertilizersand pesticides; theinitial gainsin production, however have been followed by rapid declines, and increased dependenceon chemical inputs. The damageto the soil has been incalculable.

In view of thesefacts, Nepal must proceed with caution, making every effort to distinguish short-term from long-term advantages, in order to minimizetheadverseimpacts of globalization. Although we boast of our wealth of biodiversity, the detailsareunknown. Myriad species are still undocumented and may wind up in thehands of MNCs. Weshould learn the lesson from past developmental activities (roads, dams, and so on) undertaken withoutenvironmental impact analysis: once wefritter away our resources they arelost forever. Nepal should formulate its own policies and regulations regarding patenting and extraction. Joining theWTO can and should be delayed until completion of this groundwork. Nature is Nepal's trump card, and we should playit wisely.

For correspondencetotheauthor, E-mail:roka@sify.com

\section{Refierences}

1) JN Abramovitz. 1998. Takinga stand:Cultivatinga new relationship with theworld'sforests[Worldwatch Paper 140].Washington DC:WorldWatch Institute

2) MVallianatosand ADurbin.1998. Licencetoloot:The MAl and how tostopit. Washington DC: Friendsofthe Earth. $49 p$ 